\title{
The Combined Learning in Higher Education. An Experience Through the PBL
}

\author{
Brenda Luz Colorado Aguilar, Rubén Edel Navarro
}

\begin{abstract}
The present study is based on the Blended Learning (B-learning) method using the Project Based Learning (PBL) as a teaching strategy. The students' performance can be valued through face- to- face sessions and on-line interactions when they created business projects as an approach to real situations of business life. To carry out this study, the students use the Canvas model, as a systematic prototype integrated by nine interrelated blocks that enable the comprehension about the different activities to follow for the creation of a business model in a holistic and simple way. As a result of this mixed study, it was found out that the professors make the most effective contribution to B-learning. This is due to the fact that they are in charge of the coordination, organization and planning of the teaching-learning process in general. They have to look for the best teaching strategies and technological resources to achieve their educational aims. Throughout the course, the professor's role is to motivate the student in order to make a final product which can connect his/her educational activities with real life situations. Meanwhile the student is carrying out the project, he needs to solve complex problems.
\end{abstract}

Index Terms - Blended learning, higher education, project-based learning (PBL), learning activities, learning environments.

\section{INTRODUCTION}

By taking advantages of the technology benefits which enable the students to collaborate and interact, and the participation of the professor as a facilitator in the educational processes, blended learning is a strategy in which the professors plan their lessons that integrate activities for the students to interact in both the traditional classroom classes and the on-line learning style.

Therefore, when technology is used in the student's learning process, it's very important to identify its pedagogical value by designing specific strategies. In the case of PBL (Muñoz

and Maldonado, 2011), state that, in higher education, for the students to construct concepts when they learn by solving problems, innovated educational processes with appropriate strategies to work in complex situations are required.

It is by using the Project Based Learning (PBL) strategy that knowledge management, students, tasks and activities to promote meaningful and pragmatic experiences are integrated.

In this way, the research carried out was to evaluate the blended learning by using the PBL as a teaching strategy in the subject named Technological Solutions Applicable to the Organizations (TSAO) of the Administration career in the University of Veracruz, Xalapa, campus Veracruz, México. That 40-hour-subject was taught in one semester as a workshop

Brenda Luz Colorado Aguilar. Departamento de Investigación de la Escuela Normal Veracruzana “Enrique C. Rébsamen”, Xalapa, Ver., México.

Rubén Edel Navarro. Laboratorio para la Innovación y Desarrollo Regional LIDer-Lab, Universidad Veracruzana, Veracruz, México. which included face to face classes, on-line classes (the institutional platform, facebook platform and the design and structure of websites); the searching and reading of the information as well as the individual and group work done by the students, and the final evaluation which graded all the activities done in the final product.

This integrated product was the creation of a business project that had to be published in a website designed by each working team. The business project integrated the Canvas model elements created by Alexander Osterwalder, an enterprise researcher (Márquez, 2010). The diagram represents a systematic prototype integrated by nine interrelated blocks that enable the comprehension about the different activities that guide the creation of a business model in a holistic and simple way.

In this regard, the aims to get the students interact with the business environment and include what they have learned throughout their higher education to apply it in real life were achieved. Therefore, the learning activities involved the environments, the teaching strategies and the management of learning in higher education, as well as the meaning of learning according to the business administration students' opinion.

The research problem was tackled with the following question: What is the didactic contribution of B-learning strategy through PBL in a higher education context? The general objective approach was 1) to evaluate the students' learning experience in blended learning by using the PBL.

The specific objectives were: 2) to analyze the learning activities when working with the PBL principles and 3) to analyze the technology types used for designing the business projects as final products of the course.

The study was structured based on the revision of literature, the epistemological framework, the methodology and the presentation and discussion of the results found out in a mixed study. It mainly focused on the qualitative approach in which it was concluded that the effective contribution to blended learning is the professor for his/her coordination, organization and learning environment planning, the teaching strategies and the selection of the appropriate technological resources. In conclusion, the professor's support was a significant aspect throughout the course because he/she encourages the student to solve complex problems through a final product which connects the learning activities with real life situations.

\section{BLENDED LEARNIGN}

Key Blended learning is the integration of technology to diversify the education process in a way that each learning setting is represented by the dynamic of cognitive processes that emerge from learning situations with the student. The use 
of on-line and face-to-face learning experiences enable to combine the interaction, interrelation and active participation settings between professors-students, students-professors.

Thus, the combination in the learning process that deals with the integration of technology has been called flexible learning by different authors (Salinas, 1999), semi-attendance (Bartolomé, 2002), hybrid model (Marshall, 2003), mixed models (Bartolomé, 2004), combined learning (Bartolomé, 2004).

According to (Cabero, Llorente and Román, 2004), it refers to two modalities that were considered opposite in the past; and according to Contreras, Alpiste, Eguia (2006), the combination of attending university classes and taking them through technology.

Leading the way, Solano (2013), stands out that the use of different teaching methodologies and the collaborative work are the components of B-learning. He identifies the use of different digital tools, face-to-face sessions and individual learning as well as traditional education and on-line activities.

In this way, Poon (2013) defines blended learning as the combined learning centered on the student in which he/she, by means of his/her active and effective participation enables better learning results, access, sense of community, flexibility, effective use of the resources and his/her own satisfaction.

In Osorio and Duart's point of view (2011), the analysis of interaction in mixed learning settings comes from the education activities between professors and students. They were determined based on a case study of a post grade curriculum taught by using the combined modality in a Colombian university.

In the previously mentioned study, it was found out that the construction of the knowledge may be enhanced by means of working on authentic activities, generating, at the same time, settings to accomplish better results in learning and academic achievement; notwithstanding, good conditions and characteristics are needed in the development and design of such activities in which the combined settings, the characteristics and practices of professors and students working together can be efficiently used.

Halverson, Graham, Spring, Drysdale and Henrie (2014), conducted a case study at the Nottingham Trent University (NTU) in the United Kingdom. They analyzed the students' learning experience through B-learning method based on the professors and students' opinions. The evaluation was carried out by giving questionnaires to nine professors of different subjects to answer four groups of questions about blended learning: knowledge and experience of learning, design and use of technological resources, and evaluation of learning. Apart from this, an on-line survey which evaluated blended learning was given to 200 students. The survey was divided in four groups of questions: learning experiences, general satisfaction of students, observations about their learning and in the final section they were asked to make a comparison between blended learning and face-to-face learning.

As a result, suggestions about the amount of money, time, effort and technology infrastructure to perform the case study are obtained. Human resources and training to manage this type of education modality are also required

Thus, in different researches, blended learning is used to combine different areas, share experiences about the use of technology and integrate learning strategies to achieve the best contribution to the teaching-learning process.

\section{PBL AS A DIDACTIC STRATEGY}

Technology is closely related to pedagogy which, by means of its appropriate teaching strategies, involves the student in the learning environment. According to Maldonado (2008), carrying out the PBL as part of the curriculum, is not a new conception. It is conceived as an integrating strategy rather than a complement because it is an important component of the teaching-learning process.

In accordance with Huber (2008), the first proposals of PBL are found between 1900-1933; they were the creation of a setting for exchanging ideas, decision taking and action planning with the purpose of making a specific product at the end of the task.

Rodríguez and Cortés state (2010), PBL strategy is a guide of the students' progress by diagnosing problems, giving feedback and evaluating general results of the achieved learning.

Montes (2015), considers PBL as an active strategy for students. It is based on making projects in which they develop critical thinking, problem-solving skills, and the ability of working in teams

In this sense, the ABP are conceived as the integral process that authentically tasks are completed in practice through activities (Rodriguez and Cortés 2010), structured as follows:

- Designing a final product

- Identifying a specific environment

- Searching the topics

- Designing a plan to carry out a project

- Designing and elaborating a product

Here is where Osterwalder's Canvas model is used in the TSAO course. It was considered to be appropriate to design a business project by following the systematic process of Canvas model. It is a diagram of interrelated elements that permits to analyze systematically the way to create a functional enterprise.

Thus, by applying their original ideas, searching about the local enterprises, and planning their proposition, the students created a business project. Therefore, the Canvas model was suggested as a guide or systematic process for the students (Fig. 1). According to this model, the students start with the central element of the diagram which is the value proposition. It is connected to the blocks on the right side of the diagram which represents the relationship channels with the customers. The left side shows the relationship with the resources and the necessary activities to keep the value proposition of the enterprise. The blocks at the bottom side refer to the income and costs generated when the enterprise is working.

According to Marquez (2010), each element is defined in the following way:

- Value Proposition. To identify the main reasons that make an enterprise stands out in the business market drawing attention to its competitive value.

- Customer relationship. It means the communication with the customers as parts of the commercial services and activities of the enterprise. 
- Distribution channels. They refer to the means by which the enterprise keeps contact with the customers to inform them about its products and services.

- Customer segment. It represents the type of customer the enterprise requires.

- Income sources. Here it is where the different forms to obtain income for the enterprise are specified.

- Key activities. They are the enterprise operations to establish relationship with customers and suppliers by they both follow a didactic strategy in accordance with the business topic of the TSAO subject.

In this context, it is important to consider that for analyzing, identifying and selecting the technological resources, according to Colorado and Edel (2012), their pedagogical usability -feature that permits, based on the education evaluation-, implementing strategies that closely relates didactics and technology.

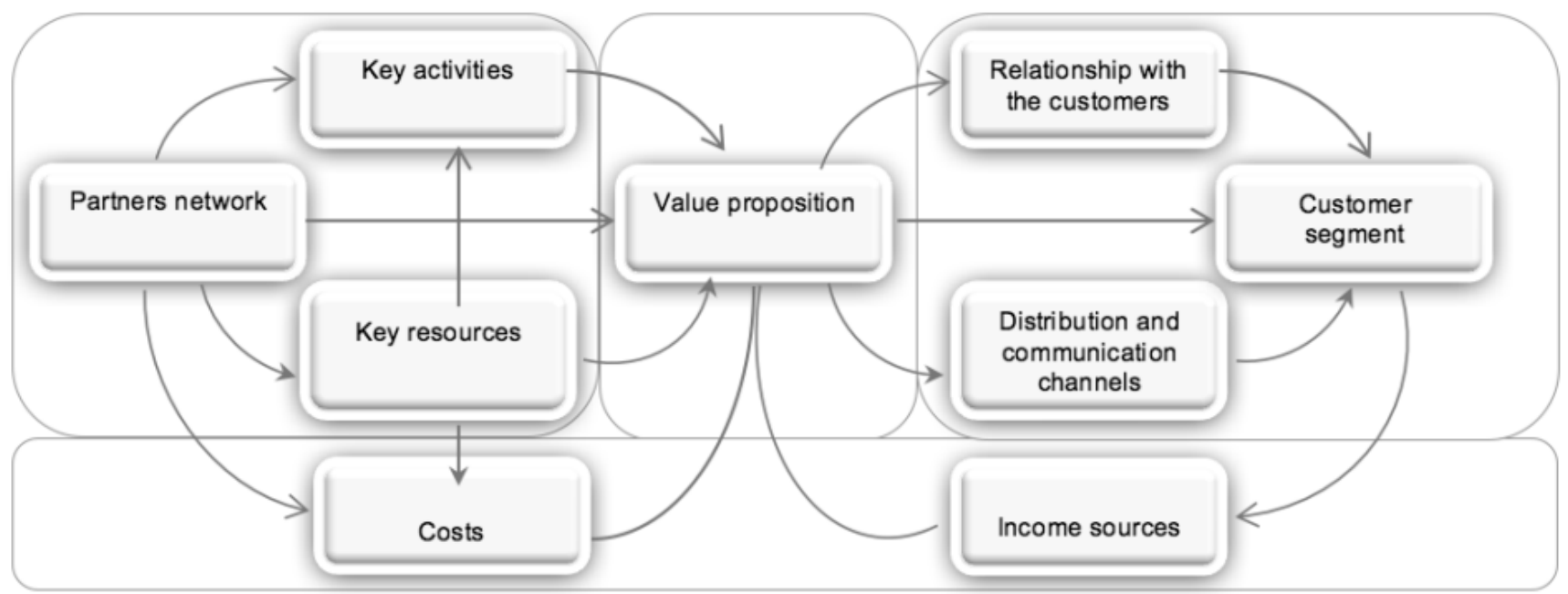

Fig.1. Canvas model

\section{EPISTEMOLOGICAL FRAMEWORK}

In face-to-face education, the abilities to establish relationship with other people are promoted; and in on-line education, with the evolution of virtual learning, the interaction as a process is promoted, too. This type of interaction is defined according to Osorio and Duart (2011), as cognitive and social actions between student-student, and student-professor to carry out learning activities. When the learning scenarios are appropriate, students feel highly motivated; so, meaningful learning is accomplished. In this study and throughout a higher education subject, a research question to know the didactic contribution of B-learning based on the PBL was stated.

means of the key resources to define the value proposition since the beginning.

- Key resources. They refer to the physical, intellectual, human and financial resources necessary for an enterprise to run.

- Network of partners. It consists of those alliances the enterprise establishes with its partners, suppliers, and members so as the effectiveness of the enterprise prevails.

- Network of partners. It consists of those alliances the enterprise establishes with its partners, suppliers, and members so as the effectiveness of the enterprise prevails.

- Cost structure. The outlays an enterprise has, to run efficiently.

Thus, the systematic model of Canvas was used to make the final product of the course based on the PBL guidelines in which technology and pedagogy are mixed in such a way that
The general objective of the study case is 1) to evaluate the students' learning experience in a mixed-mode learning by using the PBL and as specific objectives 2) to analyze the learning activities based on the PBL guidelines and 3) to choose carefully the types of technology to write a business project as a final product of the course.

\section{THEORIES THAT SUPPORT THE STUDY}

To articulate the theoretical support of the mixed-mode learning contribution to the students' learning, the contributions of mediated-learning theory and multimedia-learning theory were analyzed. In this regard, the professor's role was a key component to bring together facilitation, didactics and technology use.

\section{A. Theory of mediated learning experience}

In the theory of mediated-learning experience, it is noticeable the professor's role as a mediator-facilitator of the strategies that encourage the student towards learning. Feuerstein and Lewin-Benham (2012), state that a facilitated -professor - students relationship is established in such a way that students' motivation about the meaning of something and the experience of doing it are planned on purpose. In this context, the mixed-mode learning brings together the professor's facilitation (as the main component), the face-to-face classes and on-line settings (Fig. 2).

The main components to carry out the teaching-learning practice are comprised in a process that starts with the lesson planning in which the professor identifies the activities, 
strategies and evaluation of learning. Then he/she continues with the digital resources to monitor the students constantly. It is worth noting that the quality and quantity of learning pace increases when mediation comes from experienced-facilitators (Tébar, 2009).

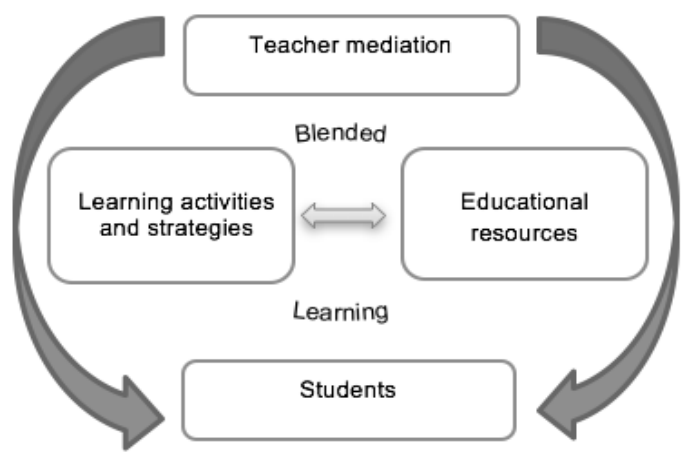

Fig. 2. The teaching environment in blended learning mediation

In this model, the professor's role is as mediator-facilitator and designer of learning activities that enable the student to develop information, communication and collaboration competencies. The key of the authentic professor's facilitation is the selection of appropriate technology that helps students learn meaningfully. That is, as Ferreiro and Vizoso (2008) say, professors shall use the technological resources - there are too many nowadays and have great possibilities- to make things better and optimize all the components of the teaching-learning process.

\section{B. Cognitive Theory of multimedia learning}

Furthermore, as Andrade-Lotero (2012) say, the main assumptions of the cognitive theory of multimedia learning (CTML), developed by Mayer in 2005, based on the principles of the theory of cognitive workload (TCW) of Sweller (1994); tackle the form to improve learning by using electronic means with the participation of the professor in the instructional design. With this regard, the professor's role is as a planner, a designer, an organizer of the resources and settings which will be the educational atmosphere of the students.

So, the principle of CTML establishes that the educational process is effective when the characteristics of the human condition are considered. In this way, the selection, organization and classification of information and instructional materials are important so as not to overload the students' cognitive process and therefore their learning may be diminished (Andrade-Lotero, 2012). According to Mayer, Heiser and Lonn (2001), people learn better by showing them literacy and images than only through literacy. Therefore, CTML studies the way to explain the meaningful results that come from the integration of both elements; when the images and words or text combine appropriately to issue a structured message in order to enable students to understand.

For this reason, it is important to remark the use of technology in the educational process by highlighting the professor's facilitation when he establishes the atmosphere, the strategies, the materials and resources clearly articulated with didactics.

\section{Methodological Design}

The study was analyzed by using a mixed-method design based on a consistent sample for both approaches. Thirty-five students participated in the quantitative study; the survey technique with a structured questionnaire was applied on line. The survey was divided in three sections (experience on B-learning, the PBL didactic strategy, and opinion about the technological environments developed). The reliability of the instrument was evaluated by using the split halves method and the result was a percentage of .89 The content, construct and criterion validity were evaluated by means of an operationalization of variables table by using the variables of the study.

It is important to point out that the qualitative study was conducted as an inquiry process to approach "the world out there" and understand, describe and explain the social phenomenon deeply (Gibbs 2012), categories of analysis by using corresponding sub-categories from the data processing in the qualitative analysis software MAXQDA were obtained. Five students participated as key informants. Here is the criteria used to select the key informants: (1) having been a TSAO student at the accountancy and business administration faculty, (2) having worked actively individually and in teams in the TSAO subject and (3) being willing to answer the complete survey.

For this reason, it is important to remark the use of technology in the educational process by highlighting the professor's facilitation when he establishes the atmosphere, the strategies, the materials and resources clearly articulated with didactics.

\section{DEVELOPMENT OF TEACHING STRATEGY}

The TSAO subject belongs to the disciplinary area of the business administration program at the University of Veracruz. It focuses on the development of the competencies in the students to evaluate how efficient and effective the information technology is in companies. (UV, 2012).

In this regard, in the TSAO course, the active participation of the students to identify the type of technology suitable to the enterprises, and the development of a functional business project quite close to the enterprise real function is promoted.

For this reason, it is necessary to ask trigger questions to analyze, in a preliminary way, situations to solve complex problems. In this respect, the market, the enterprise competitiveness and the different situations the students should consider for a business project were analyzed.

Thus, by using technology and having the professor's assistance during the learning process, some elements are combined to contribute, in this way, to the student's own educational process.

The learning activities were carried out through face-to-face, and on-line sessions on the institutional learning platform, a closed group on facebook for the student-student and students-professor's communication and feedback. As a final product, in teams, the students designed websites to publish 
each business model structured during the course and saved the documentation of their prototype in a digital file.

Therefore, the subject was developed in both ways: face-to-face sessions and on-line classes as it follows below:

- Institutional platform. For the coordination of the course; the documentation storing (an action guide of the business project, and sources of information; as well as a means to email the activities that support the final project; and the written work documenting the business project.

- Closed group and discussion forum (facebook) For student-student and professor-student interactions. The forum used to discuss and give feedback throughout the course.

- Websites: The use of free platforms on internet to design and publish the business projects.

To carry out the business project, the general indications and guidelines of the Canvas business model were followed. According to them, an enterprise should be set up systematically. Those steps were adapted for the TSAO subject, for which working teams of 5 students each one were organized. Based on the research questions made on the diagram (Table 1), these teams structured their business project throughout the course.

Following the Canvas model, the students started in the middle of the diagram, where the value proposition is. It is the essential element because it guides the students all the time; they need to identify what makes an enterprise outstands and causes the customers prefer to buy there to at any other enterprises with the same line of business; that is called the value-added concept. On the other hand, the other elements are complementary. On the right side of the diagram, the students analyzed the type of communication they shall have with the customers during the commercialization process, the type of customers they will sell their products and provide service, the means of communication they would use to let people know their products or service. This last aspect was done by analyzing the current technology resources the students usually use to buy products and can be suitable to incorporate in their business idea. The students also analyzed, on the same side, the element concerning the way of sale and service revenue.

On the left side of the diagram, the students answered questions about the activities and resources an enterprise requires to accomplish its value proposition, as defined at the beginning; as well as its main business partnerships such as its trading partners, providers, and so forth, to make the enterprise efficient. Last but not least, the cost determination for the enterprise to start working.

Throughout the course, complementary activities were carried out in face-to-face sessions and, later on, they were uploaded to the institutional digital platform to be evaluated. There was also a constant feedback and discussion on the facebook forum

At the end of the course, the students made a presentation of their business project in face-to-face sessions. They talked about the enterprise web-site as well as its promotional products to illustrate the sale and service the enterprise offers (Fig. 3).

As an example of the business project, an enterprise called BisKotakafé which makes coffee and cookies is presented. There, the students made an analysis of its value proposal and suggested coffee-essence products which are sold near the region. The cookies packages were made of recyclable material and sold to the general public and, upon request, for any kinds of events.

In this way, by answering the trigger questions, the students faced real life situations when they put into practice a business idea that integrated all the necessary elements to run a regional enterprise efficiently.
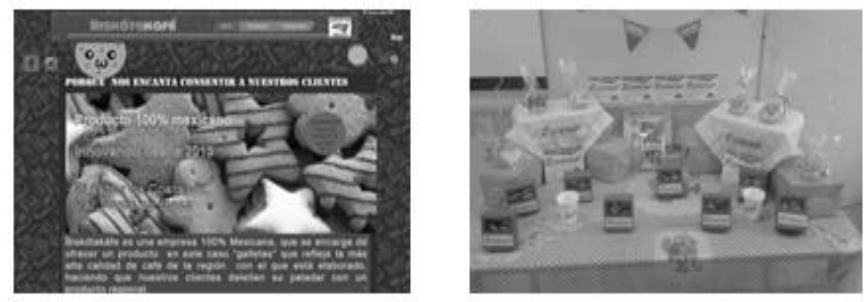

Fig. 3. Business Project of coffee cookies as an example of the business project 
The Combined Learning in Higher Education. An Experience Through the PBL

Table 1. Key questions that guide the design canvas model

\begin{tabular}{|c|c|c|c|c|}
\hline Partners network & Key activities & \multirow{4}{*}{$\begin{array}{c}\text { VALUE } \\
\text { PROPOSITION } \\
\text { What is the } \\
\text { value-added concept } \\
\text { of my enterprise that } \\
\text { makes it stand out? }\end{array}$} & Customer relationship & \\
\hline \multirow[t]{3}{*}{$\begin{array}{l}\text { What are the main } \\
\text { business partnerships } \\
\text { the enterprise sets up } \\
\text { with its suppliers and } \\
\text { partners in order to be } \\
\text { effective? }\end{array}$} & $\begin{array}{l}\text { What are the key activities and } \\
\text { processes for my enterprise to } \\
\text { carry out the value proposition? }\end{array}$ & & $\begin{array}{l}\text { What kind of relationship do I keep } \\
\text { with the customers during pre-sale and } \\
\text { post-sale services (Sale executives, } \\
\text { personalized sale, contact-center, } \\
\text { among others) }\end{array}$ & \multirow[t]{3}{*}{$\begin{array}{l}\text { What kind of customers } \\
\text { the company offers the } \\
\text { service or products? }\end{array}$} \\
\hline & Key resources & & $\begin{array}{l}\text { Communication and distribution } \\
\text { channels }\end{array}$ & \\
\hline & $\begin{array}{l}\text { What are the most important } \\
\text { resources of my enterprise? } \\
\text { (human resources, infrastructure, } \\
\text { technology) }\end{array}$ & & $\begin{array}{l}\text { What means of communication do I } \\
\text { use with the customers to let my } \\
\text { products known? (advertisement, web } \\
\text { sites, etc.) }\end{array}$ & \\
\hline \multicolumn{3}{|c|}{ Costs } & \multicolumn{2}{|l|}{ Income } \\
\hline \multicolumn{3}{|c|}{ What is the operating cost of an enterprise? } & \multicolumn{2}{|c|}{$\begin{array}{c}\text { What are the ways by which sale income and the enterprise services } \\
\text { are received? }\end{array}$} \\
\hline
\end{tabular}

\section{PRESENTATION AND DISCUSSION OF RESULTS}

The learning experiences were carried out through face-to -face and on-line environments. In both, the students's participation was remarkable during the TSAO course. Innovative ideas prevailed as seen through the business idea proposals considering the real matters new enterprises face. The study focused on determining the didactic contribution of blended learning and PBL in university subject. Therefore, the suitability of B-learning using PBL and the appropriate technological resources were evaluated through a qualitative study. Thus, five students as key informants participated. After evaluating their perceptions, some areas of their interpretations were identified. They were divided in three groups with sub-groups (Table 2).

Table 2. Categories of the qualitative approach analysis

\begin{tabular}{|c|c|c|}
\hline \multicolumn{3}{|c|}{ Categories of Analysis } \\
\hline Learning environment & $\mathrm{S} \mathrm{u} \mathrm{b} \mathrm{c} \mathrm{a} \mathrm{t} \mathrm{e} \mathrm{g} \mathrm{o} \mathrm{r} \mathrm{i} \mathrm{e} \mathrm{s}$ & Experience on the use of ICT \\
\hline Face-to-face classes & Connection between the school and the real world & Type of tool and/or resource \\
\hline Implementation of technology & Working in teams & Appropriateness of use \\
\hline Appropriate learning & Learning experience & \\
\hline
\end{tabular}

The category of learning environment was divided in three sub-categories of analysis: face-to-face classes, implementation of technology and appropriate learning. All of them show the students' perception about the way the TSAO course was carried out. It involved face-to-face students' interaction and the appropriate learning achieved (Fig 4).

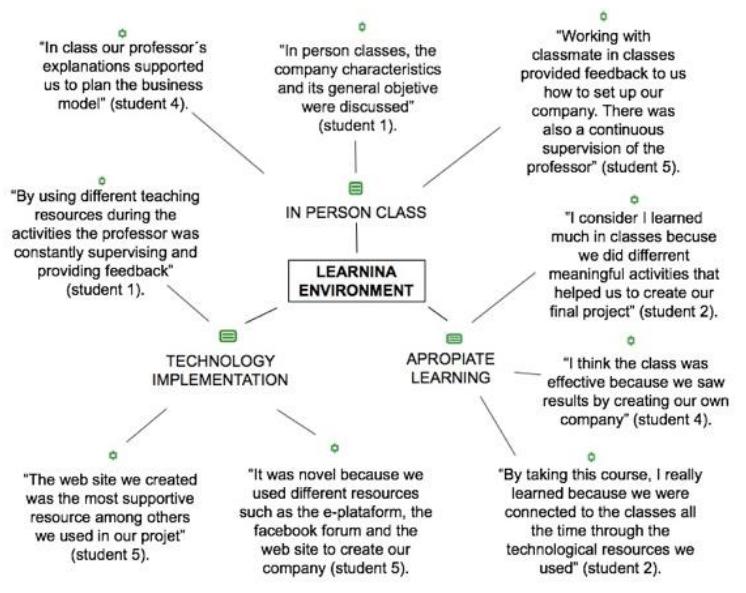

Figure 4. Students' perceptions about the learning environment
In this way, the students evaluated the face-to-face classes as the ones in which the dynamic of the course, the general explanations, the professor's objectives, as well as the feedback on the activities the students give to each other were set up.

About the category called implementation of technology, the students identified it as a working tool that enables the professor's facilitation and his/her revision on time, as well as the innovation by using different virtual settings to set up their final project. The students showed approval about using web-sites when creating an enterprise.

Concerning the category called appropriate learning, the students said that the use of technology was good because it helped them to make their final product; and there was a continuous professor-student and student-student communication. The students found out that learning was much more meaningful.

The category called integrating project was formed by three subcategories of analysis: connection between the school and the real world, teamwork, and learning experience.

Thus, in this category the students' perception related to the integrating product of the course was inferred. Connecting 
educational activities with real situations of the enterprise life generated a language experience in which teamwork was significant. In fig. 5, it can be noticed that the three subcategories of the integrating project had about the same weight which means they were really integrated and balanced according to the students' favorable perception. They presented a frequency of the codes between 22 and 27 opinions.

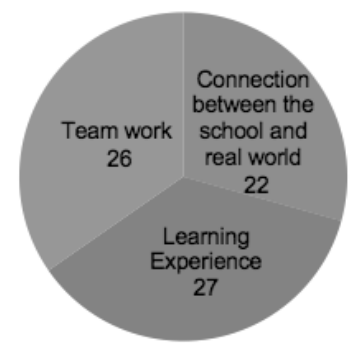

Figure 5. Analysis subcategories of the integrating Project

Thus, the students' opinions in favor of applying the PBL strategy to make a product that made them learn and feel motivated are clearly showed in Table 3 .

Here there are some opinions of the students supporting that situation: "well, I think it was very interesting, I had never worked on a similar project in which I learned things to apply in real life" (student 3). "I learned to take decisions as a group; and to consider my classmates' capabilities and attitudes to make a good project" (student 1); "I learned that starting a business is not easy but when you finish, you feel really satisfied" (student 5).

In this way, the teaching strategy was analyzed as a part of the educational environment in which the students worked in teams actively and used the PBL criteria. This work was done as Rodríguez and Cortés (2010) say, the design and elaboration of the final product should be done by identifying the specific environment where it should be applied, documenting oneself to support it. All of this was immersed in the action plan of the project management which operated according to Canvas' systematic and pragmatic model.

Thus, they considered that working in teams was important because it gave them the best opportunity for taking decisions as a group, being respectful, listening and communicating with the other members of the team, and being tolerant of the other team members' opinions; but especially, having experienced the higher education subject which according to Noguera and Gros (2014), when working groups are formed among students, there should be joint and not performing tasks individually responsible.

Table 3. Students' perception when creating a final product by using the BPL

\begin{tabular}{|c|c|c|}
\hline \multicolumn{3}{|c|}{ Integrating Project } \\
\hline $\begin{array}{l}\text { Connection between the school and the real } \\
\text { world }\end{array}$ & Working in teams & Learning experience \\
\hline $\begin{array}{l}\text { "Well it was interesting, I had never worked in a } \\
\text { similar project in which I learned its application } \\
\text { in real life" (student } 3 \text { ). }\end{array}$ & $\begin{array}{l}\text { "I learned to take decision as a group; to consider my } \\
\text { classmates' capabilities and attitudes to make a good } \\
\text { Project" (student 4). }\end{array}$ & $\begin{array}{l}\text { "I learned that starting a business is not easy but } \\
\text { when you finish, you feel really satisfied" (student } \\
\text { 5). }\end{array}$ \\
\hline $\begin{array}{l}\text { "The course activities let me increase my } \\
\text { knowledge and grow as an individual; deal with } \\
\text { my classmates but they especially made me feel } \\
\text { motivated to start my own business" (student 1). }\end{array}$ & $\begin{array}{l}\text { "I learned to listen to new ideas and proposals about } \\
\text { our new business model, have a good } \\
\text { communication and make a collaborative work" } \\
\text { (student } 1 \text { ). }\end{array}$ & $\begin{array}{l}\text { "The use of Canvas model in the project allowed the } \\
\text { professor and the students to carry out the activities } \\
\text { in order" ( student } 1 \text { ). }\end{array}$ \\
\hline $\begin{array}{l}\text { "The responsibility to be in charge of an area of } \\
\text { a company which is a good experience" (student } \\
\text { 5). }\end{array}$ & $\begin{array}{l}\text { "The main achievement was face-to-face } \\
\text { communication and virtual one. I learned to listen to } \\
\text { other classmates and be tolerant with their' } \\
\text { opinions" (student } 3 \text { ). }\end{array}$ & $\begin{array}{l}\text { "I liked this way of working because we followed an } \\
\text { order and we knew what to do in the different } \\
\text { activities as the setting up of our Enterprise" } \\
\text { (Student 2). }\end{array}$ \\
\hline
\end{tabular}

About the category of the Experience in the use of ITCs, the opinions focused on the technology used to carry out the activities of the course and the way technology makes an enterprise to be more functional (Table 4).

The subcategories were integrated according to the learning environments the students used. In the case of the web site designed to set up the enterprise, they said it provided a meaningful learning experience by considering how much technology they can use to make their enterprise more functional and efficient. In a student's point of view: "I learned the way an enterprise can design its web page, how its advertisement works, and the technology that can be used to permit its products and services to be known" (student 4). About using the electronic institutional platform for learning, the students said it was a useful link for the coordination of the project, storing the information on line and uploading the activities. They considered it to be remarkable and easy-to-use. According to one student's opinion "The electronic platform was a guide because if we forgot something, it was always available there and it also had the lesson plan" (student 5).

And finally, the use of facebook, allowed a better interaction between professor-student, student- professor in the closed group and discussion forum to interact at any time and any place. Therefore, the students found it as a means by which they communicated better with the professor since he/she was available even in the distance by using the forum to answer their doubts and reinforce what they had learned in a face-to-face class. Here there is, one student's perception: "By facebook you can keep contact with the professor and ask any questions about something you did not understand; and you do not need to wait until the following class" (student 5). 
The Combined Learning in Higher Education. An Experience Through the PBL

Table 4. Perception about the types of tools and learning resource

\begin{tabular}{|c|c|c|}
\hline \multicolumn{3}{|c|}{ Type of tool and/or resource } \\
\hline Website & Institutional platform & Facebook (closed group and forum) \\
\hline \multicolumn{3}{|c|}{ Appropriate use criteria } \\
\hline $\begin{array}{l}\text { "It was something new for me because I had not } \\
\text { designed a web site before. At the beginning, I } \\
\text { thought it was going to be complicated but as I was } \\
\text { practicing I learned a lot" (1). }\end{array}$ & $\begin{array}{l}\text { "This is the first time I use a platform } \\
\text { designed for school activities" (student } 3 \text { ). }\end{array}$ & $\begin{array}{l}\text { "In Facebook you can keep contact with the professor } \\
\text { and ask any questions about something you did not } \\
\text { understand. You do not need to wait until the following } \\
\text { class." (Student 5). }\end{array}$ \\
\hline $\begin{array}{l}\text { "I learned how an enterprise designs a web page; } \\
\text { how it makes its advertisement work and the } \\
\text { technology used to make its products and service } \\
\text { known" (student 4). }\end{array}$ & $\begin{array}{l}\text { "I had not used the platform before but it was } \\
\text { easy. Besides technology allows professors to } \\
\text { have a register and control of the students" } \\
\text { (student } 3 \text { ). }\end{array}$ & $\begin{array}{l}\text { "Facebook is a strategic tool since most of the students or } \\
\text { the people are usually connected to that social network } \\
\text { which enables communication a little bit more" Student } \\
\text { 2). }\end{array}$ \\
\hline $\begin{array}{l}\text { "On the web site, we were setting up our enterprise } \\
\text { by integrating what we were learning in class" } \\
\text { (student } 3 \text { ). }\end{array}$ & $\begin{array}{l}\text { "The electronic platform was a guide because } \\
\text { if we forgot something, it was always } \\
\text { available there and it also had the lesson } \\
\text { plan" (student 5). }\end{array}$ & $\begin{array}{l}\text { "Facebook helps us to keep a close relationship between } \\
\text { the students and the professor so as to reinforce the } \\
\text { knowledge learned in class" (student } 4 \text { ). }\end{array}$ \\
\hline
\end{tabular}

In general terms, talking about the qualitative analysis (Fig. 6), it can be noticed that the learning environment and the integrating project had a a higher percentage; that means the students' opinions prevailed when they were asked about using the PBL in the course because they had an action guide based on the Canvas model. This fact provided the students with an effective learning experience as it can be read from one student indubitable opinion: "I liked this way of working because we followed an order and we knew what to do in the different activities such as the setting up of our enterprise" (student 2).

About the experience on using ICT, it was a category that showed the functionality the students found out in the learnig resources of the course, and the way an enterprise can use technology to run more efficiently. Technology was used more as a part of the learning environment and a way to carry out the integrating project than a technological means.

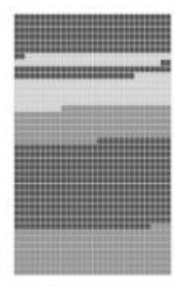

Student 1

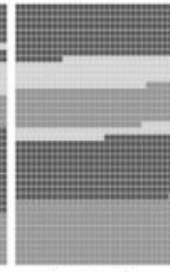

Student 2

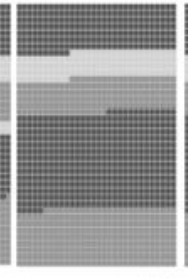

Student 3

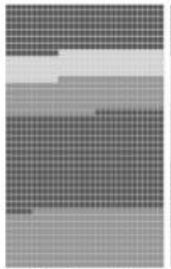

Student 4

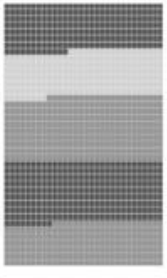

Student 5
Learning environment $\square \quad$ Integrating project $\quad$ ICT use experience spent, the strategies to be used, the classes instructions, and the selection of educational resources to create effective learning environments.

Regarding the institutional e-learning platform, it was considered to be an appropriate learning environment in which the students interacted with the professor. It was a favorable tool for the coordination of the course according to the students' opinion (Fig. 7).

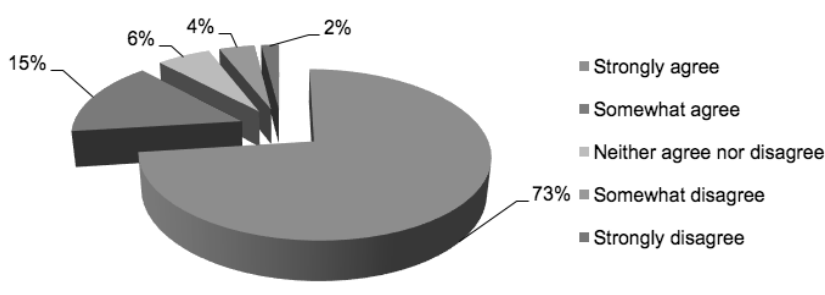

Fig. 7. Opinions of students from about the institutional platform

Even though on-line environments had a specific and determined objective for each activity of the course, it was important to consider the students' evaluation to identify in which of them, they liked to work the most and which one was found as the most supportive for the activities done. Thus, the students had mixed opinions about the learning environments throughout the course (Fig. 8).

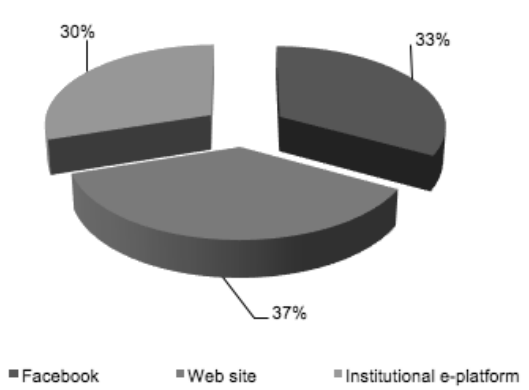

Fig. 8. Learning platforms which students located more taste and functionality
Fig. 6. Categories of qualitative analysis of greater weight

Concerning the quantitative study, the group of informants was formed by $63 \%$ female students and $37 \%$ male students whose ages were between 18 and 22 years old. When they were asked their opinions regarding the learning environment, the combination of face-to-face classes and the

use of different technological resources throughout the course, $87 \%$ percent of them gave positive responses.

Thus, when blended learning is used in a teaching process, according to Agudelo and Salinas (2015), implies the integration of well-designed spaces where the acquisition and construction of knowledge can be conceived as part of planning and organizing learning situations, the time to be

\section{furcionality}


When students were asked about the activities in which they have learned the most, they pointed out it had been when they used the Canvas model. According to Marquez (2010) this prototype provides a powerful and clear synthesis to set up a functional business (Fig. 9).

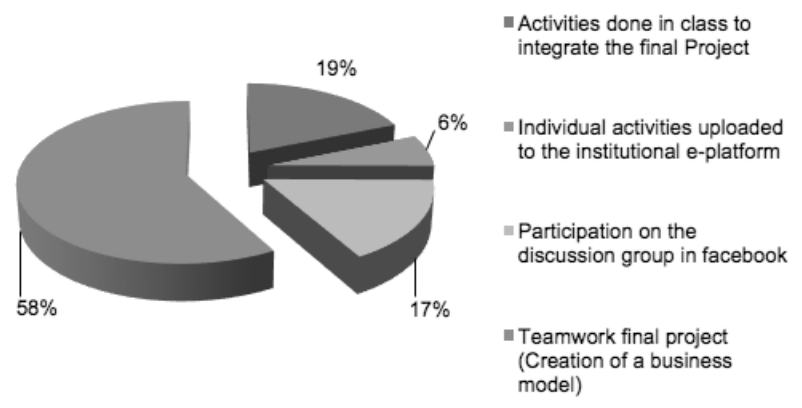

Fig. 9. Activities in which students believe they had achieved greater learning

About the discussion group created on Facebook to promote the interrelation among students, as a support in their final project and used to post their ideas of business in the forum, most of the students agreed it was useful (Fig. 10).
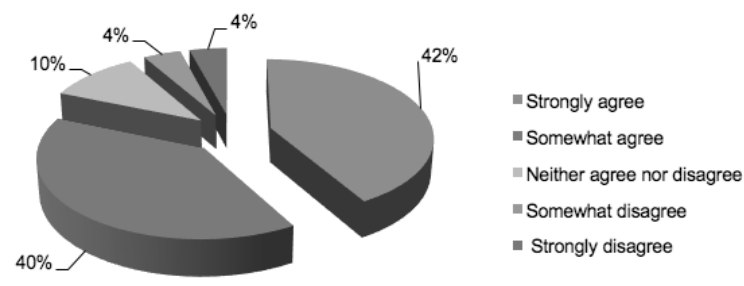

Fig. 10. Facebook as a communication means

Applying the PBL strategy, according to Rodríguez and Cortés (2010) who recommend the identification of a final product within the subject area of research; and develop a management plan for the project, the design and elaboration of a product according to a specific environment meant an integral process in which, in an authentic way, the students developed their own ideas to create their business projects.

For that purpose, the students were asked about using a defined plan of action by using the PBL that guides the learning activities throughout the course. It generated a positive experience as you can see in Fig. 11.
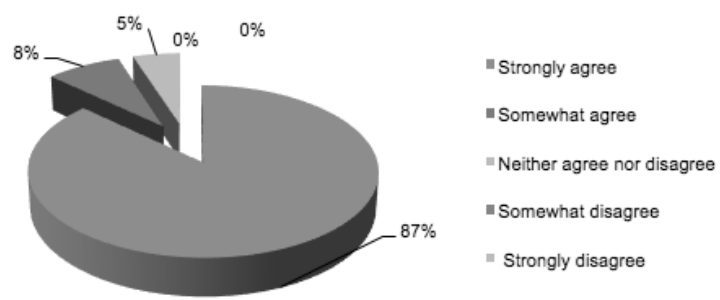

Fig. 11. Opinions about the use of PBL as a learning strategy

In this regard, it worths saying that professor's mediation and the CTML basis were appreciated by the students.
Throughout the course, the combination of materials, learning resources and tools, learning strategies and learning environments permitted the harmonization without overloading the working environment but achieving the collaboration. Thus, the students expressed their satisfaction in working together and learning from each other so as to exceed communication problems. They were, even changed into business and social communication skills. In this regard, Noguera and Gros (2014) say that when the students start working on a complex task, they realize about the importance of working together and, due to this fact, management and communication aspects can be seen among groups. Besides, at the same time, in a joint work manner, they made a product which was a project created throughout the course and applied to real life. Thereby, by using the PBL strategy, the students' performance when working together, was remarkable.

In this study, the contribution of blended learning was noted by pointing out that the design, re-creation and organization of a learning environment requires a comprehensive professor's mediation supported by pedagogical criteria so as the students can achieve meaningful learning experiences which, in this studio, was based on PBL.

So, it's important to point out that the professor's performance as a learning mediator of on-line, face-to face or mixed-mode environments according to Tébar (2009), represents a humanization agent in cultural transmision considering the serious change in culture and information and communication means.

In summary, the professor's mediation allows the students to understand better because he/she encourages them to be willing and gives a constant educational feedback.

\section{CONCLUSIONS}

Learning environments define interrelation, collaboration, joint-work and cognitive-process developments between professors and students to generate learning.

In this context, the TSAO subject joined environments of professor-student participations and interrelations and remarked the competency to develop in the students which was the evaluation of information technology performance used by the enterprises to measure their efficiency and effectiveness (UV, 2012).

Therefore, the research done focused on the evaluation of effectiveness of blended learning in a higher education subject whose purpose is the development of learning about the importance of technology in an enterprise context.

In this way, the student's approach to technological environments in order to integrate them in the creation of a business model which would stand out the technology functionality in the enterprise, represented an interrelation between the classes and the real world.

For this reason, the PBL strategy which delimited specifically how a project should be developed was applied. Moreover, by using the Canvas model more specifications to set up a functional enterprise were provided. The specifications were about the different situations and common issues to set up 
an enterprise and the technology the students could include to make their business model more functional and competitive.

The students' perception analysis based on the qualitative study permitted to identify categories that delimited the situations carried out during the teaching-learning process.

In those categories, the most representative students' perceptions were delimited. As a result, the students' showed their approval about learning and the importance of working in different activities throughout blended learning by using the PBL in the course.

Consequently, professors and students' roles as components of the teaching -learning process have been evolving in a lesser or greater extent depending on the educational model of the institution and the professor's attitude towards the idea of being a guide or an organizer promoting an active, propositional, and participative learning for the students. It shall be considered that students learn by "constructing knowledge that has meaning according to the way they perceive the world and their own experience and what they want to know. Besides, learners do not learn alone but within social and communication relationships (Gros, 2011).

Thus, in this study, it was estimated that learning activities permitted to combine learning environments and teaching strategies as well as the learning management with higher education students concluding on the importance of the professor to coordinate, organize and plan the educational environment, teaching strategies and the appropriate technological resources. The professor's role as an organizer of the learning processes was remarkable; it was also recognized the use of technology as a goal in itself in the business project development which permitted the students to participate in a propositional project for society.

\section{REFERENCES}

[1] Agudelo, O., Salinas, J. (2015). Flexible Learning Itineraries Based on Conceptual Map. Journal of New Approaches in Educational Research. 4(2), 70-76. Retrieved from http://naerjournal.ua.es/article/view/v4n2-1

[2] Andrade-Lotero, L. (2012). Teoría de la carga cognitiva, diseño multimedia y aprendizaje: un estado del arte. Revista Internacional de Investigación en Educación, 5 (10): 75-92. Retrieved from http://www.redalyc.org/pdf/2810/281024896005.pdf

[3] Cabero, J., Llorente, M., Román, P. (2004). Las herramientas de comunicación en el «aprendizaje mezclado». Pixel-Bit. Revista de Medios y Educación, (23):27-41.

[4] Colorado, B., Edel, R. (2012). Usabilidad de las TIC en la Práctica Educativa. Revista de Educación a Distancia, 30, 1-30. Retrieved from http://www.redalyc.org/articulo.oa?id=36802303

[5] Contreras, R., Alpiste, F., Eguia, J.(2006). Tendencias en la educación: aprendizaje combinado. Theoria, 15 (1), 111-117. Retrieved from http://www.redalyc.org/pdf/299/29915111.pdf

[6] Feuerstein, R. y Lewin-Benham, A. (2012). What learning looks like. Mediated learning in theory and practice. Retrieved from http://bit.ly/2cDtXUE.

[7] Ferreiro y Visozo (2008). Una condición necesaria en el empleo de las TIC en el salón de clases: La mediación pedagógica. Revista Posgrado y Sociedad, 8 (2): 72-88. Retrieved from http://ow.ly/iFak305nW3y

[8] Gros, B. (2011). Evolución y Retos de la Educación Virtual. Construyendo el e-learning del siglo XXI. Diseño de la colección: Editorial UOC. Retrieved from

http://openaccess.uoc.edu/webapps/o2/bitstream/10609/9781/1/TRIPA_ _e-learning_castellano.pdf

[9] Gibbs, G. , B. (2014). El análisis de datos cualitativos en Investigación Cualitativa. España, Marid: Morata.

[10] Halverson, L., Graham, C., Spring, K., Drysdale, J., \& Henrie, C. (2014). A thematic analysis of the most highly cited scholarship in the first decade of blended learning research. Internet and Higher Education. Retrieved from http://ow.ly/t2EC305nWiS 20: 20-34.

[11] Huber, G. (2008). Aprendizaje activo y metodologías educativas. Revista de Educación, Special Issue, 59-81. Retrieved from http://www.duoc.cl/cfd/docs/aprendizaje-activo-metodologias-ducativas. pdf

[12] Márquez, J. (2010). Innovación en modelos de negocio: La metodología de Osterwalder en la práctica. Revista MBA EAFIT, 1, 30-47. Retrieved from

http://www.eafit.edu.co/revistas/revistamba/documents/innovacion-mod elo-negocio.pdf

[13] Mayer, R., Heiser, J. \& Lonn, S. (2001). Cognitive Constraints on Multimedia Learning: When Presenting More Material Results in Less Understanding. Journal of Educational Psychology, 93 (1), 187-198. Retrieved from http://ow.ly/x4MC305ogju

[14] Montes, C. (2015). Active Learning Inspired by Team-Based Learning and Project-Based Learning. Opción. 31 (3), 867-882. Retrieved from http://www.redalyc.org/html/310/31045567045/index.html

[15] Muñoz, J., Maldonado, T. (2011). Aprendizaje con base en proyectos para desarrollar capacidades de Problematización en educación superior. Revista Electrónica Actualidades Investigativas en Educación, 11, (1), 1-19. Retrieved from http://www.redalyc.org/pdf/447/44718060014.pdf 11

[16] Noguera, I., Gros, B. (2014). Indicadores para la construcción de prácticas colaborativas en entornos virtuales de aprendizaje. Revista Latinoamericana de Tecnología Educativa. 13 (1), 51-62. Retrieved from http://relatec.unex.es/article/view/1155

[17] Osorio, L. \& Duart, J. (2011). Análisis de la interacción en ambientes híbridos de aprendizaje [Interaction Analysis in Hybrid Learning Environment]. Comunicar, 37: 65-72. Retrieved from http://ow.ly/RLIU305ohtf

[18] Poon, J. (2013). Blended Learning: An Institutional Approach for Enhancing Students' Learning Experiences. Journal of online learning and teaching, 9 (2), 271-288. Retrieved from http://jolt.merlot.org/vo19no2/poon_0613.htm

[19] Rodriquez, E., Cortés, M. (2010). Evaluación de la Estrategia Pedagógia "Aprendizaje Basado en Proyectos": Percepción de los estudiantes. Avaliação, Campinas; Sorocaba, SP, 15 (1), 143-158. Retrieved from http://ow.ly/d72Y305ohy2

[20] Solano, O. (2013). El aprendizaje combinado y el desarrollo de las habilidades requeridas para la comunicación escrita. Revista Electrónica Educare, 17 (3), 293-313. Retrieved from http://www.redalyc.org/pdf/1941/194128798015.pdf

[21] Tebar, L. (2009). El profesor mediador del aprendizaje. Colombia, Bogotá: Magisterio.

[22] Universidad Veracruzana (2012). Programa de la experiencia educativa de Soluciones Tecnológicas Aplicables a las Organizaciones. Retrieved from http://www.uv.mx/sea/files/2012/12/SolucionesTecnologicas.pdf.

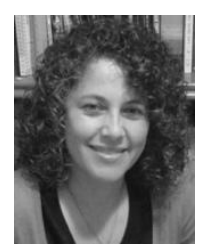

Ph.D in Educational Systems and Environments by the University of Veracruz. Member of the Consejo Nacional de Ciencia y Tecnología (CONACYT) Thematic Network, Area 3 (Communication and Information Technologies). She has a published book, scientific papers in national an international journals in the field of Educational Models and Environments mediated by ICT. Currently working as a research and professor at the Benemerita Escuela Normal Veracruzana, "Enrique C. Rebsamen" in Xalapa, Veracruz. Professional trainer in the qualitative data analysis software MAXQDA.

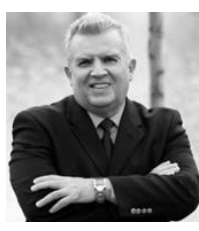

Researcher at the Consejo Nacional de Ciencia y Tecnología (CONACYT) of México. He has been recognized at the top-2000 scientist ranking from Mexican Institutions by the Spanish National Research Council, and distinguished with the International Award for Educational Innovation at the Nova Southeastern University (NSU) in Florida, USA. His scientific work in the field of technology-mediated learning is reflected in books and publications in scientific journals. 